Pengajaran Literasi Informasi ... (Lis Setyowati)

\title{
PENGAJARAN LITERASI INFORMASI DENGAN KONSEP GAMIFICATION DI PERPUSTAKAAN PERGURUAN TINGGI
}

\author{
Lis Setyowati \\ Pustakawan Fakultas Teknik \\ Universitas Diponegoro
}

Game mungkin bukan hal yang baru bagi perpustakaan di Indonesia. Bentuk pemanfaatan game di perpustakaan di Indonesia biasanya berupa quiz dalam kegiatan orientasi perpustakaan. Namun sebenarnya aplikasi game di kegiatan perpustakaan bisa jau lebih luas daripada itu, termasuk dalam kegiatan pengajaran literasi informasi. Prinsip-prinsip game dapat digunakan untuk mengembangkan pengajaran literasi informasi agar kegiatan ini lebih menarik bagi pemustaka dan sekaligus membuat para pemustaka lebih terlibat aktif dalam proses pembelajaran. Penerapan prinsip-prinsip game dalam kegiatan yang bukan merupakan kegiatan bermain ini dikenal dengan istilah Gamification. Gamification merupakan tren yang kian meluas dan kian mendapat tempat, tidak hanya di dunia pendidikan, pengembangan personal maupun dunia bisnis. Mengingat manfaat yang bisa dipetik dari Gamification, maka perpustakaan juga perlu belajar bagaimana mengaplikasikannya dalam dunia perpustakaan, terutama untuk pengembangan fungsi pendidikan, yakni pengajaran literasi informasi.

Kata kunci: perpustakaan, literasi informasi, game, Gamification

\section{Pendahuluan \\ Latar Belakang}

Literasi informasi kini dianggap semakin penting, seiring dengan semakin kompleksnya lansekap informasi. Ketika orang seolah dibombardir dengan banyak informasi, dari berbagai arah, dalam berbagai format dan kualitas yang berbeda-beda, maka mereka mulai merasa kewalahan dalam menghadapi kompleksitas informasi. Banyak pihak yang mulai menyadari perlunya keterampilan untuk mencari, mengevaluasi, dan menggunakan informasi untuk membantu memecahkan permasalahan. Kemampuan ini dapat membantu dalam pembuatan keputusan yang lebih baik.

Ketika kesadaran akan pentingnya literasi informasi semakin meluas, maka inisiatif untuk menjadikan keterampilan ini sebagai bentuk modal manusia (Setyowati, 2015) juga mulai banyak dilakukan di perpustakaan, terutama perpustakaan perguruan tinggi dan perpustakaan sekolah. Pendekatan yang paling sering digunakan dalam pengajaran literasi informasi adalah metode instruksional. Pendekatan ini cenderung bersifat formal, serius dan tidak memancing orang untuk memperhatikan apa yang disampaikan. Ketika pendekatan ini dilakukan, maka muncul keluhan bahwa pelatihan literasi informasi yang diikuti membosankan (Smale (2011); van Meegan dan Limpens (2010); Doshi dalam Markey et al., 2009). Demi peningkatan efektivitas pembelajaran, maka keluhan keluhan seperti ini perlu ditindaklanjuti.

Untuk itu perlu dicari alternatif metode lain yang bisa digunakan. Salah satu opsi yang bisa dipilih adalah dengan aplikasi Gamification dalam pembelajaran literasi informasi. Gamification merupakan metode yang mulai dikembangkan dalam dunia perpustakaan. Metode ini dilakukan dengan menerapkan prinsip-prinsip game dalam aktivitas yang dilakukan di perpustakaan.

\section{Tinjauan literatur}

Bermain seringkali dianggap sebagai aktivitas untuk mencari hiburan. Permainan (game) sendiri sebenarnya adalah" a system in which players engage 
in an artificial conflict, defined by rules, that results in a quantifiable outcome" (Salen dan Zimmerman dalam Walsh, 2015). Dari definisi yang dikemukakan oleh Salen dan Zimmerman ini, dapat dipahami bahwa game adalah suatu sistem dimana para pemainnya terlibat dalam suatu konflik semu, dimana aktivitas yang dilakukan dalam bermain dibatasi oleh aturanaturan, dan hasil akhir dari permainan bisa diukur.

Definisi lain dari game adalah "a rule-based formal system with a variable and quantifiable outcome, where different outcomes are assigned different values, the player exerts effort in order to influence the outcome, the player feels attached to the outcome, and the consequences of the activity are optional and negotiable" (Juul dalam Walsh, 2015). Definisi ini memberikan batasan bahwa game merupakan suatu sistem formal yang dilandasi aturan-aturan, dengan hasil yang bervariasi dan dapat diukur. Dalam game ini dimana hasil yang berbeda akan memiliki nilai yang berbeda, para pemain bisa menerapkan strategi untuk mencapai hasil yang diinginkan. Para pemain akan merasa dipengaruhi hasil yang didapatkan dan konsekuensi dari kegiatan ini bisa dipilih dan disepakati bersama.

Dari definisi yang dikemukakan di atas maka dapat disimpulkan bahwa game merupakan suatu sistem yang memancing pemainnya untuk menghadapi tantangan yang ditawarkan untuk mencapai hasil maksimal. Kemudian untuk mendapatkan hasil yang diinginkan, para pemain harus mematuhi aturan-aturan yang berlaku, dan mengembangkan strateginya sendiri.

Game merupakan kegiatan yang bersifat bebas dan sukarela. Karakteristik lain dari game adalah melibatkan fantasi dimana orang akan berada di luar kehidupan kesehariannya. Mereka tidak serius namun dapat menarik perhatian secara intens dan tidak dikaitkan dengan tujuan materialistik, memiliki batasannya waktu dan ruang, memiliki peraturan yang jelas, membentuk kelompok sosial, dan memiliki tantangan (Huizinga dalam Amr, 2012). Karakteristik game yang fun namun bisa membuat orang secara serius bermain menjadi aspek penting, karena ini berkaitan dengan motivasi. Salen dan Zimmerman (dalam Amr, 2012) menyatakan bahwa motivasi orang bermain game adalah karena kesenangan yang dialami, yakni rasa senang, penghargaan, kepuasan dan kegembiraan. Pengalaman inilah yang menjadi kunci dalam sebuah game, yang mampu menarik perhatian orang untuk serius memainkannya.

Serius tapi menyenangkan. Nilai inilah yang dianggap sebagai kunci efektivitas pencapaian tujuan dalam bermain game. Ini pula yang ingin diterapkan untuk kegiatan di luar kegiatan bermain. Prinsip-prinsip game bisa diterapkan dalam banyak aspek kehidupan, tidak hanya untuk pengembangan diri, yakni peningkatan produktivitas. Prinsip-prinsip game juga digunakan untuk meningkatkan kesetiaan pelanggan dalam dunia bisnis. Game juga mampu meningkatkan motivasi siswa, dalam bidang pendidikan. Aplikasi prinsipprinsip game untuk kegiatan yang diluar kegiatan bermain seperti itu disebut sebagai Gamification.

Istilah gamification dikemukakan oleh Nick Pelling di tahun 2002, namun baru pada pertengahan tahun 2010 istilah ini banyak digunakan (Kim, 2012). Gamification sendiri bisa dijelaskan sebagai "the application of game elements in nongaming situations, often to motivate or influence behavior" (Educause, 2011). Dengan kata lain, Gamification adalah penerapan elemen-elemen game dalam situasi non-game dimana metode ini seringkali digunakan untuk memberikan motivasi atau mempengaruhi perilaku orang. Definisi lain dikemukakan oleh Felker (2014), yang menyatakan bahwa "the process of applying game mechanics and game thinking to the real world to solve problems and engage users". Dari penjelasan ini dapat diketahui bahwa Gamification merupakan proses menerapkan mekanika dan pemikiran ala game dalam dunia nyata. Gamification pada hakikatnya mener- 
apkan beberapa karakteristik positif dari sebuah permainan untuk kegiatan yang bukan permainan (non-game).

Contoh bentuk gamification yang paling populer adalah aplikasi "Foursquare". Ini merupakan aplikasi online yang menggunakan elemen gamification. Aplikasi ini memberikan warna baru untuk aktivitas yang biasa dilakukan sehari-hari, dengan memberikan kesempatan bagi pemakainya untuk melakukan check in di suatu tempat atau memberikan komentar untuk tempat tersebut. "Foursquare" memiliki karakteristik sama dengan game. Orang menggunakannya aplikasi ini tanpa ada tanpa paksaan. "Foursquare" juga memiliki aturan, yakni check in hanya bisa digunakan manakala pemakainya berada di dekat tempat tersebut. "Foursquare" memberikan feedback langsung, dengan sapaan "Welcome back," manakala aplikasi ini mendeteksi bahwa pemakai aplikasi pernah berkunjung ke tempat tersebut. "Foursquare" juga menawarkan hadiah berupa badge. Dengan semua fiturnya, aplikasi ini menjadikan aktivitas keseharian yang biasa saja menjadi lebih menyenangkan (Kim, 2015).

Namun gamification tidak sekedar membuat suatu aktivitas menjadi menyenangkan. Menurut Deese (2016), penerapan gamification memberikan manfaat: membantu perkembangan aspek kognitif, dan pada beberapa kasus, perkembangan aspek fisik orang dewasa; dan gamification meningkatkan tingkat peran aktif peserta didik dalam kelas; gamification membantu peserta ajar dalam memahami materi. Dengan manfaat yang demikian, maka Gamification diterapkan di banyak bidang, termasuk di bidang perpustakaan.

\section{Metode}

Melalui tinjauan literatur, tulisan ini akan menguraikan apa yang dimaksud dengan gamification, bagaimana aplikasi gamification dalam perpustakaan, khususnya aplikasi gamification dalam pengajaran literasi informasi. Juga diberikan beberapa contoh inisiatif aplikasi gamification dalam pengajaran literasi informasi. Terakhir dibahas juga tentang tantangan yang mungkin dihadapi ketika menerapkan gamification dalam pengajaran literasi informasi di Indonesia.

\section{Pembahasan}

\section{Gamification di perpustakaan}

Gamification merupakan metode yang dianggap ampuh karena kemampuannya untuk menarik perhatian orang, melibatkan mereka dalam kegiatan yang diinginkan, dan bahkan mempengaruhi perilaku mereka (Kim, 2015b). Tidak mengherankan bila gamification kini banyak diterapkan oleh banyak kalangan, untuk berbagai tujuan.

Perpustakaan juga melihat potensi penerapan gamification. Penerapan gamification di perpustakaan dapat dilakukan untuk aspek pendidikan pemustaka ataupun dalam manajemen perpustakaan. Pada aspek pendidikan, gamification dapat dilakukan untuk pengajaran kepada pemustaka agar mereka bisa menjadi pembelajar mandiri. Dari sisi manajerial, gamification dapat dimanfaatkan sebagai bagian dari promosi jasa layanan perpustakaan, mempromosikan program kegiatan perpustakaan agar bisa menarik lebih banyak orang untuk mengikuti, dan juga meningkatkan kesadaran di kalangan pemustaka tentang sumberdaya yang ada di perpustakaan. Dengan gamification, maka diharapkan tingkat partisipasi pemustaka akan meningkat. Peningkatan partisipasi pemustaka pada akhirnya akan dapat digunakan sebagai dasar untuk mendapatkan pendanaan yang lebih besar untuk pengembangan perpustakaan (Kim, 2015a).

Secara lebih detail, Felker (2014) menguraikan penerapan gamification di perpustakaan. Menurutnya, aplikasi gamification diantara adalah 
dalam bentuk:

1. Pengenalan perpustakaan (Library Orientation) Penggunaan gamification dalam orientasi perpustakaan akan memberikan kesan positif terhadap permustaka. Orientasi perpustakaan dengan gamification akan memberi kesan menyenangkan. Ini menjadi modal dalam membangun hubungan jangka panjang antara pemustaka dan perpustakaan. Tidak hanya itu, kegiatan ini bisa juga menjadi sarana untuk memberitahukan hal-hal penting dan mendasar yang perlu diketahui pemustaka tentang jasa layanan perpustakaan

2. Penggunaan sumber-sumber informasi yang ada di perpustakaan

Scoring atau pemberian score merupakan mekanisme dalam game yang dapat dimanfaatkan untuk mendorong pemustaka untuk memanfaatkan sumber-sumber informasi perpustakaan. Dengan memanfaatkan data sirkulasi, maka dapat diketahui angka pemanfaatan bahan pustaka. Dari data sirkulasi juga dapat diketaui siapa yang meminjam buku, kapan dan seberapa sering sebuah buku dipinjam. Dengan sistem scoring, maka setiap transaksi peminjaman akan mendapatkan nilai, yang terus akan diakumulasi, dan kemudian dibuat ranking. Peringkat ini yang menjadi dasar pemberian hadiah bagi pemustaka. Mekanisme pemeringkatan berdasarkan skor ini diharapkan dapat memotivasi pemustaka untuk lebih sering memanfaatkan sumbersumber informasi di perpustakaan.

3. Kegiatan membaca (Reading Programs)

Di Amerika, perpustakaan umum memiliki program Summer Reading. Ini merupakan program yang dilakukan untuk mengisi liburan musim panas para pelajar. Program summer reading ini dirancang seperti game, dengan menerapkan sistem hadiah, bahkan mendorong kompetisi di kalangan para pemustaka. Banyak peluang untuk menggunakan gamification untuk mendorong anak-anak agar lebih memahami literatur yang mereka baca, misalnya dengan membuat game yang berkaitan dengan tokoh-tokoh dari buku yang pernah dibaca. Permainan seperti ini mungkin bisa memperluas minat baca anak.

4. Pengajaran literasi informasi

Game dapat digunakan untuk mendukung metode pengajaran literasi informasi yang dilakukan secara tatap muka. Game dapat dimanfaatkan untuk memperdalam pemahaman akan konsep yang rumit untuk dipahami. Konsep akses terbuka (open access) misalnya, bisa dijelaskan dengan menggunakan game. Pemustaka menjadi pemain yang bisa memilih peran sebagai pihak peneliti yang memiliki kepentingan untuk menerbitkan hasil penelitiannya, ataupun sebagai penerbit jurnal. Aturan permainan akan ditetapkan agar mereka bisa belajar tentang negosiasi ongkos produksi informasi, ongkos penyediaan akses dan juga informasi tentang orang yang benar-benar bisa mengakses informasi. Game seperti ini memungkinkan mahasiswa untuk menggali realita yang ada terkait dengan akses tertutup dan akses terbuka. Para pemain pada akhirnya akan belajar tentang kontrol informasi dan kelangkaan informasi.

\section{Gamification pengajaran literasi informasi}

Dari uraian di atas, telah dapat diketahui bahwa salah satu bentuk gamification di dunia perpustakaan adalah Gamification pengajaran literasi informasi. Gamification pengajaran literasi informasi bukanlah sekedar upaya perpustakaan untuk mengikuti trend yang sedang berkembang, namun lebih karena kebutuhan untuk menjawab tantangan yang ada. Tantangan ini berupa 
mengajarkan literasi informasi kepada pemustaka. Menjawab tantangan ini tidaklah mudah karena diharapkan pemustaka menguasai keterampilan ini, sementara waktu yang ada untuk penyelenggararan pelatihan biasanya terbatas hanya 45 menit sampai dengan 2 jam (Van Meegan dan Limpen, 2010). Agar mereka dapat memperoleh keterampilan ini, maka pengajaran literasi informasi harus disampaikan dengan metode tertentu agar efektif.

Selain itu, metode yang digunakan dalam pengajaran literasi informasi selama ini lebih bersifat serius dan formal dengan model perkuliahan. Model pengajaran seperti ini membuat peserta cenderung bersifat pasif, padahal penelitian menunjukkan bahwa orang akan bisa belajar dengan lebih baik makala para peserta didik bersikap aktif dalam proses pembelajaran (Felker, 2014). Agar proses pembelajaran berjalan efektif, maka diperlukan teknik pembelajaran yang bisa menarik partisipasi aktif peserta ajar (Bonwell \& Eison; Prince dalam van Meegan dan Limpens, 2010).

Tantangan lain yang harus dihadapi dalam pembelajaran literasi informasi datang dari pemustaka. Pemustaka yang ada di perpustakaan perguruan tinggi merupakan generasi digital. Generasi digital dikenal juga sebagai digital natives, maupun generasi game. Generasi ini sangat dekat dengan teknologi karena mereka tumbuh besar dengan komputer, video game dan internet. Lingkungan tumbuh yang ada mengakibatkan mereka memiliki karakteristik gaya kognitif yang unik. Karakteristik ini berupa: menyukai segala sesuatu secara cepat; terbiasa multitasking; terbiasa berpikir konseptual, tidak linear; menyukai hal-hal yang bersifat visual ketimbang teks, berjejaring, menyukai aktivitas yang memancing mereka untuk aktif, menyukai kegiatan bermain, selalu mempertimbangkan hasil akhir yang bisa diperoleh, imajinatif, dan sangat menguasai teknologi (Prensky, 2001b).

Dengan karakteristik ini, maka situasi belajar yang akan menarik perhatian mereka adalah situasi belajar yang mampu memfasilitasi kebiasaan dan gaya kognitif mereka. Kegiatan yang paling sesuai untuk menjawab kebutuhan generasi ini adalah belajar melalui game atau yang dikenal dengan game-based learning. Game-based learning adalah metode pembelajaran yang menggunakan aplikasi permainan yang dirancang khusus membantu proses pembelajaran (Prasetyo, 2014).

Para ahli berpendapat bahwagame merupakan metode yang ampuh untuk digunakan dalam proses pengajaran kepada generasi digital natives (Van Meegan dan Limpens, 2010). Game dapat menarik peserta belajar untuk terlibat aktif dalam proses belajar, meningkatkan motivasi belajar mereka, sekaligus meningkatkan kemampuan penyelesaian masalah (Young, 2016). Game-based learning memiliki beberapa karakteristik yang sangat mendukung proses pembelajaran. Manakala game digunakan sebagai pendekatan dalam pengajaran, maka manfaat yang didapatkan adalah (Whitton dalam Walsh, 2014):

\section{Menyenangkan (playfulness)}

Game memberikan rasa senang (pleasure) (Deterding \& Dixon, 2011). Rasa senang yang dialami ketika bermain games ini menimbulkan efek perasaan santai, sehingga membuat peserta didik menerima apa yang disampaikan dengan lebih mudah (Prensky, 2001a).

2. Latihan (practice)

Latihan memungkinkan adanya proses refleksi atas kemajuan yang dicapai, kesempatan untuk terus mengatasi tantangan yang sama dan merumuskan strategi bermain sampai tujuan dapat diraih. Dalam game, pemain diberi ruang untuk bereksplorasi, karena game memang menyediakan ruang "aman" bagi para pemain untuk berbuat salah adanya proses trial and error. Ini memotivasi mereka untuk menjalani proses pembelajaran dan 
pada akhirnya memperoleh pemahaman yang lebih mendalam atas materi yang disampaikan. Kebebasan ini juga yang membuat orang memiliki keberanian untuk mengembangkan keterampilan.

3. Keterlibatan (engagement)

Engagement seringkali dianggap sebagai karakteristik utama game-based learning. Karakteristik ini muncul karena adanya perpaduan berbagai elemen game yang membuat pemain merasa nyaman ketika bermain. Dalam game, dituntut adanya sikap aktif pemain. Pemain menjadi pemegang kontrol atas proses yang berlangsung karena merekalah yang membuat keputusan atas semua strategi dan tindakan yang akan dilakukan. Aspek afektif seperti inilah yang bisa menarik minat, meningkatkan motivasi, meningkatkan rasa percaya diri para pemain. Ini menjadi pengalaman belajar yang memiliki dampak positif, apapupun hasil dari game yang mereka peroleh (Broussard and Oberlin dalam Young, 2016). Ini dapat menciptakan kreativitas, inovasi dan gagasan baru.

4. Scaffolding

Scaffolding memungkinkan aktivitas dilakukan secara bertahap, dimulai dari tahapan yang lebih rendah ke tinggi, sesuai dengan tingkat kesulitan yang ada. Dengan demikian, maka penguasaan materi akan lebih mendalam, karena diawali dengan hal-hal yang lebih mudah terlebih dahulu.

5. Umpan balik (feedback)

Dalam game, setiap tindakan akan mendapatkan umpan balik secara langsung. Umpan balik yang diterima menjadi dasar untuk memikirkan kembali dan menata ulang strategi yang digunakan dalam bermain. Umpan balik yang cepat merupakan kekuatan dari game yang bisa digunakan dalam proses pembelajaran. McGonical (dalam Young, 2016) menyatakan bahwa umpan balik merupakan salah satu keunikan dari game yang dapat mendukung proses belajar. Umpan balik, walaupun dalam bentuk negatif, selalu bersifat konstruktif.

6. Literasi digital (digital literacy)

Ketika membicarakan game digital, game bisa menampilkan gambar dan suara secara bersamaan. Tidak hanya itu, dalam game digital ada aktivitas kompleks dimana pemain harus dapat menyimak, mengumpulkan dan memproses data. Ini merupakan kemampuan yang pada hakikatnya berkaitan dengan literasi media dan literasi informasi (Whitton, 2010). Terkait dengan literasi digital Guo dan Goh, (2016), menyatakan bahwa perilaku para pemain game yang baik sebenarnya sesuai dengan perilaku literasi informasi yang telah ditetapkan oleh Association of College and Research Libraries (ACRL). Perilaku ini dapat dilihat dari bagaimana seorang pemain merencanakan dan menetapkan apa saja tindakan yang perlu dilakukan, mencari dan mengelola informasi yang dibutuhkan untuk memenangkan permainan, dan berdasarkan informasi yang dikumpulkan dari berbagai sumber, kemudian menetapkan strategi yang dapat digunakan dalam bermain.

Mengingat manfaat yang bisa didapatkan game, maka konsep gamification, juga diterapkan di perpustakaan dalam pengajaran literasi informasi. Gamification dapat menghidupkan kelas pengajaran literasi informasi (Smale, 2011). Tidak hanya itu, pendekatan ini juga terbukti membawa dampak positif dalam proses pembelajaran di perpustakaan (Tewell dan Angell dalam Smale, 2011). Dalam pengajaran literasi informasi, games dapat digunakan sebagai sarana penyampaian konsep-konsep penting seperti: evaluasi informasi dan akses terbuka (open access). Cara ini tidak hanya 
Pengajaran Literasi Informasi ... (Lis Setyowati)

menyenangkan, tapi juga memperkaya pengalaman belajar, serta memberikan pemahaman yang lebih dalam tentang konsep yang disampaikan sehingga akan lebih mudah diserap. Dengan demikian akan memperbesar kemungkinan penerapan materi di kalangan peserta (Felker, 2014).

Penerapan konsep gamification dapat dilakukan melalui 2 cara (Felker, 2014):

1. Mencangkokkan sistem yang mirip dengan game ke dalam sistem yang sudah ada.

Contoh dari cara ini adalah menggunakan sistem "badge" atau "point" dalam kegiatan pengajaran. Badge merupakan penanda yang berfungsi sebagai hadiah ataupun bentuk pengakuan atas prestasi sedangkan point menunjukkan angka capaian hasil. Ini merupakan cara yang sederhana dan mudah diterapkan.

2. Merombak pengalaman belajar sebagai sebuah game.

Cara ini lebih rumit karena harus menemukan cara baru dan merombak pengalaman secara menyeluruh, sehingga menjadi kegiatan yang benar-benar berbeda. Beberapa sistem seperti points, badges, dan mekanisme "naik level" dapat digunakan. Untuk merancang game seperti ini tentu membutuhkan lebih banyak usaha dan waktu.

Kedua cara diatas bisa dicoba untuk pengembangan pengajaran literasi informasi. Pengembangan pengajaran literasi informasi juga bisa dilakukan dnegan mempelajari berbagai praktik-praktik yang dilakukan oleh perpustakaan lain. Inisiatif untuk melakukan Gamification pengajaran literasi informasi telah dilakukan oleh beberapa perpustakaan di luar negeri. Berikut ini adalah beberapa contoh praktik gamification pengajaran literasi informasi yang dilakukan:

Tabel 1. Praktik Gamification Pengajaran Literasi Informas

\begin{tabular}{|c|c|c|c|}
\hline No & Game & Instansi & Kegiatan \\
\hline 1 & Goblin Threat & $\begin{array}{l}\text { Lycoming } \\
\text { College }\end{array}$ & $\begin{array}{l}\text { Game digital yang } \\
\text { mengajarkan } \\
\text { plagiarisme dan } \\
\text { hak cipta }\end{array}$ \\
\hline 2 & BiblioBouts & $\begin{array}{l}\text { University of } \\
\text { Michigan }\end{array}$ & $\begin{array}{l}\text { Game } \\
\text { menggunakan } \\
\text { sistem score untuk } \\
\text { mengajarkan } \\
\text { pembuatan } \\
\text { bibliografi } \\
\text { menggunakan } \\
\text { Zotero }\end{array}$ \\
\hline
\end{tabular}
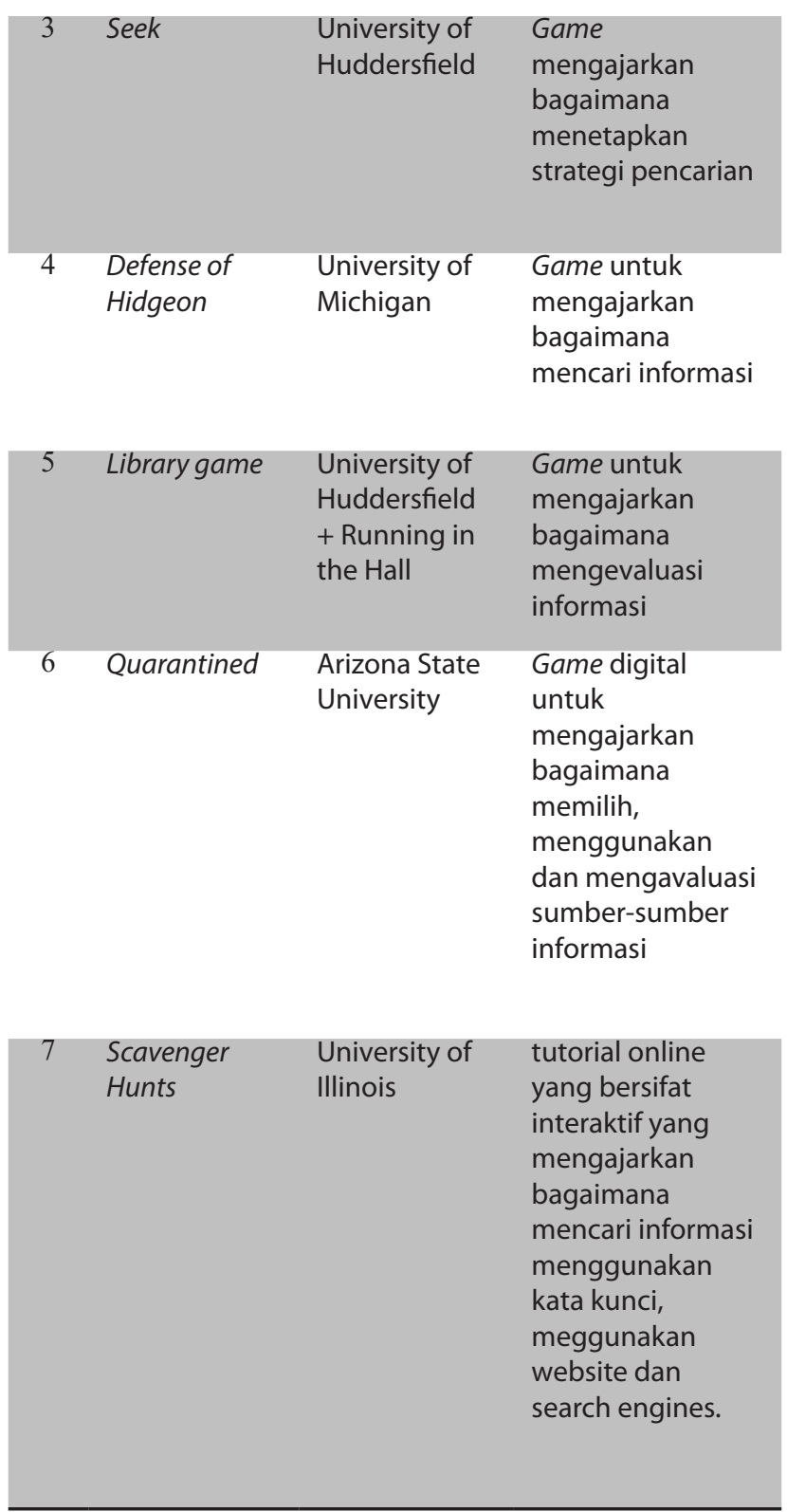

Sumber: Young (2016); Phetteplace dan Felker (2014) 
Salah satu game dalam pengajaran literasi informasi yang bisa dijadikan rujukan untuk belajar dalah Seek! Yang dikembangkan oleh University of Huddersfield.

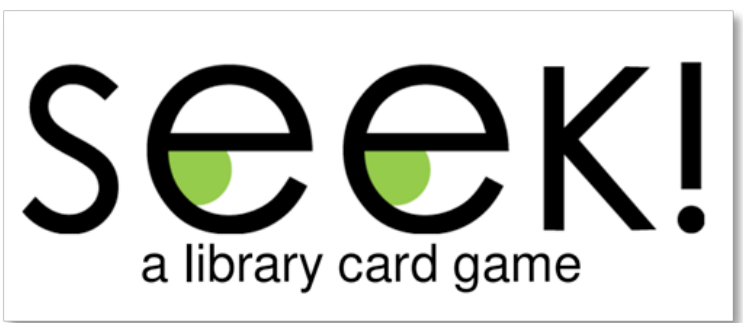

Gb. 1 Logo Seek

Seek! Merupakan permainan kartu yang bisa melibatkan 2 sampai 6 orang pemain. Permainan ini dirancang sebagai bagian dari sesi pengajaran literasi informasi. Pengajaran ini untuk mengajarkan keterampilan dalam mencari informasi, yakni: 1) menentukan konsep utama dalam rumusan masalah penelitian; 2) menentukan sinonim kata kunci; 3) penggunaan Boolean operators; 4) penggunaan wildcards dan alat bantu lain; 5) pentingnya menyimpan catatan hasil pencarian; 6) penggunaan sumber-sumber informasi di perpustakaan secara online; 7) plagiarisme; 8) pentingnya mengecek kualitas sumber informasi; dan 9) memanfaatkan bantuan pustakawan dalam pencarian informasi.

Permainan ini hanya memakan waktu 20 menit, termasuk waktu untuk pengantar dan diskusi. Pengantar disampaikan oleh instruktur sebelum permainan dimulai. Dalam pengantar, instrukstur akan memberikan penjelasan tentang pentingnya keterampilan dalam mencari informasi dan juga menjelaskan bahwa permainan yang akan dimainkan akan memberikan banyak ide yang akan membantu para pemain dalam meningkatkan keterampilan mereka dalam mencari informasi. Di akhir permainan, instruktur akan memimpin diskusi kelompok. Diskusi akan berkembang, sesuai dengan hasil permainan, namun topik yang didiskusikan bisa meliputi:

1. Adakah teknik baru dalam pencarian informasi yang mereka ketahui dari game tersebut?

2. Bagaimana menentukan kata kunci pencarian? Apa kata kunci yang biasanya diabaikan?

3. Siapa yang mendapatkan wildcard? Mengapa? Kartu yang digunakan dalam permainan ini sejumlah 72 buah, terdiri dari kartu standar (Gb. 2), kartu instruksi (Gb.3) dan kartu wildcard (Gb.4). Kartu standar berisi pertanyaan yang berkaitan dengan materi pencarian informasi ataupun instruksi untuk mengambil kartu wildcard. Sedangkan kartu wildcard berisi instruksi khusus yang harus diikuti pemain.

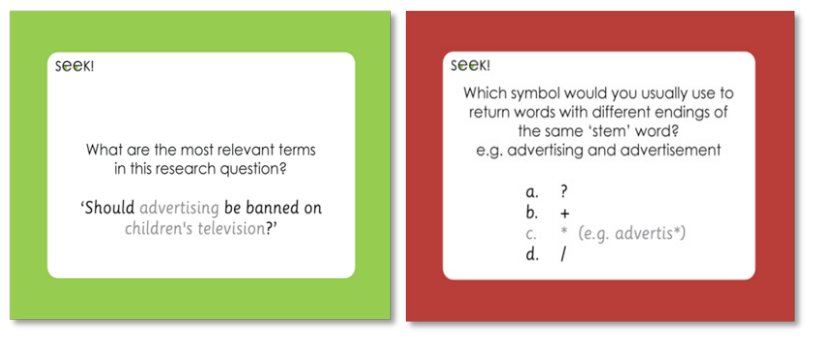

Gambar 2. Contoh Kartu SEEK!

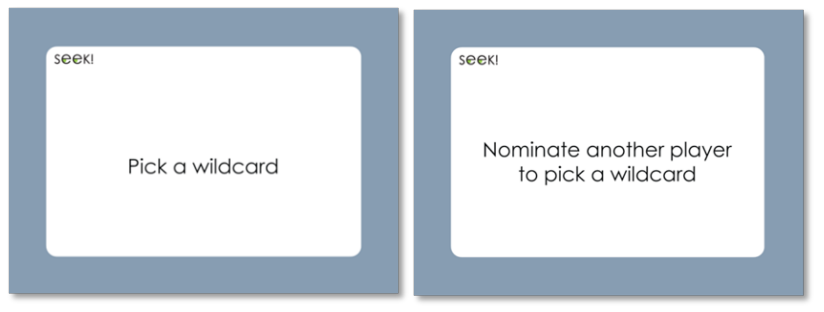

Gambar 3. Contoh Kartu instruksi!

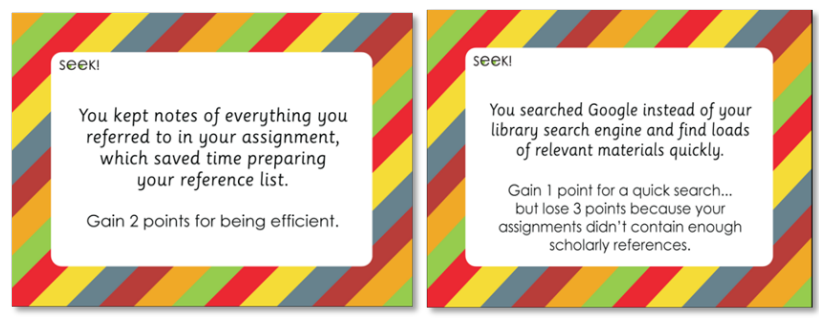

Gambar 4. Contoh Kartu Wildcard

Game ini dimainkan sama dengan permainan kartu biasa. Permainan dimulai oleh pemain yang 
Pengajaran Literasi Informasi ... (Lis Setyowati)

terakhir kali meminjam buku di perpustakaan. Masing-masing akan memegang 2 kartu untuk dimainkan. la boleh memilih kartu mana yang akan ia mainkan dan memilih pemain mana yang akan menjawab pertanyaan pada kartu yang ia mainkan. Pemain yang bisa menjawab dengan benar akan mendapatkan nilai 2, namun bila ia tidak bisa menjawab, maka pemegang kartu lah yang mendapatkan nilai tersebut. Bila sudah dimainkan, kartu harus diletakkan di atas meja. Pemain yang pertama kali mendapatkan nilai 10 akan memenangkan permainan.

\section{Tantangan Gamification pengajaran literasi informasi}

Gamification merupakan konsep yang relatif baru dalam pengajaran literasi. Usaha untuk mengadopsi dan menerapkan konsep ini di dunia perpustakaan, khususnya dalam pengajaran literasi informasi perlu didorong. Terkait dengan hal ini, beberapa tantangan yang perlu dijawab oleh pustakawan selalu pengajar literasi informasi maupun pimpinan perpustakaan adalah:

\section{Tantangan bagi pustakawan}

1. Mengembangkan semangat intrapreneurship Usaha pengembangan gamification literasi informasi tidak hanya memerlukan kemauan untuk belajar, namun juga kreativitas dan persistensi di kalangan pustakawan. Tanpa pengembangan jiwa intrapreneurship di kalangan pustakawan, maka kegiatan ini sulit dilakukan.

2. Memahami konsep gamification.

Gamification merupakan konsep yang relatif baru di Indonesia. Sejauh ini penerapan konsep gamification hanya terbatas pada penyelenggaraan kuis sebaga bagian dari kegiatan orientasi perpustakaan. Penerapan yang lebih berkembang biasanya adalah berupa pemberian hadiah kepada pemustaka yang paling rajin meminjam buku. Padahal potensi penerapannya sangat banyak. Inilah yang perlu dieksplorasi oleh pustakawan.

3. Mengembangkan keterampilan yang dibutuhkan.

Gamification memerlukan serangkaian keterampilan yang umumnya jarang dimiliki oleh pustakawan. Bila gamification diterapkan dalam pengajaran literasi informasi, maka pustakawan perlu memiliki pengetahuan yang cukup tentang pengajaran. Tidak hanya itu, walaupun game mengandung materi instruksional, game pada hakikatnya tetaplah merupakan bentuk seni. Sehingga diperlukan juga pengetahuan tentang desain grafis atau bahkan pemrograman, bila game yang dirancang merupakan versi digital.

4. Memahami kebutuhan pemustaka dan memperhatikan pengalamannya.

Pendekatan user centered approach perlu digunakan dengan melibatkan para pemustaka ketika merancang gamification dalam pengajaran literasi informasi Guo dan Goh, (2016). Masukan dari pemain akan menjadi kunci dalam perbaikan dan pengembangan game. Hal ini penting karena pada hakikatnya mereka konsumen produk. Mereka lah yang merasakan langsung dan bisa memberikan penilaian dari pengalaman yang mereka, apakah game yang dirancang cukup mampu untuk membantu mereka memahami materi yang disampaikan.

5. Mengembangkan game

Keberhasilan suatu game dalam pengajaran literasi informasi diukur dari bagaimana game tersebut dapat memenuhi tujuan pembelajaran, mampu menarik peserta untuk terlibat aktif, memberikan motivasi kepada peserta, memiliki tingkat partisipasi pemain yang tinggi, rasa frustasi pemain yang rendah. Game yang baik harus bisa menyeimbangkan 
aspek kemudahan dan kesulitan. Bila terlalu mudah, maka akan membosankan dan hilang daya tariknya sehingga tujuan pembelajaran tidak tercapai. Apabila terlalu sulit maka akan mengakibatkan munculnya rasa frustasi di kalangan pemainnya (Broussard dalam Markey et al. 2009). Selain itu, dalam merancang game juga diperhatikan pengembangan formula yang pas, yang bisa menyeimbangkan tujuan instruksional aspek "fun" dan interaksi. Dalam mengembangkan game, pustakawan perlu menetapkan tujuan yang ingin dicapai melalui pengajaran melalui game, menetapkan alat ukur yang jelas dalam mengukur ketercapaian tujuan, bagaimana mengukurnya dan menetapkan strategi perbaikannya.

6. Mengadopsi atau memodifikasi game Pengembangan game memang tidak mudah. Bila pengembangan game dirasa sulit, maka pustakawan bisa belajar dari game yang telah dikembangkan oleh pustakawan lain. Game dari perpustakaan luar negeri bisa dijadikan sebagai acuan. Tentu saja, mengadaptasi dengan mengalihbahasakan game tersebut tetap memperhatikan ketentuan hak cipta yang berlaku dan meminta izin dari pemilik hak cipta.

7. Promosi

Game yang telah dirancang perlu disosialisasikan kepada pemustaka. Promosi perlu dilakukan agar pemustaka tertarik untuk mencoba metode belajar yang baru ini. Ini juga menjadi tantangan pustakawan.

\section{Tantangan bagi pimpinan perpustakaan:}

Memberi dukungan:

1. Finansial

Pengembangan gamification literasi informasi membutuhkan biaya, tidak hanya berupa materi berupa dana, waktu, namun yang paling penting adalah pemikiran dan usaha.
Ini bukan proses yang hanya berlangsung sekali. Pengembangan gamification dilakukan melalui siklus perancangan, membuat prototipe, pengujian, aplikasi, dan mengumpulkan umpan balik. Siklus ini berlangsung terus-menerus demi proses perbaikan, dengan demikian maka biaya yang akan dikeluarkan akan banyak (Felker, 2014).

2. Memberi ruang gerak bagi pustakawan Kegiatan yang membutuhkan kreativitas ini memerlukan ruang gerak. Pustakawan perlu diberi kesempatan untuk melakukan mengeksplorasi dan bereksperimen dengan metode baru ini. Termasuk untuk belajar dari perpustakaan lain yang telah menerapkan gamification melalui studi banding.

3. Kebijakan penerapan

Game edukasi biasanya tidak bersifat sukarela, namun bila game perpustakaan didesain secara menarik, maka tanpa ada unsur paksaan, pemainnya akan mencoba. Bila motivasi untuk mencoba game belum ada, maka perlu mekanisme yang bisa "memaksa" para peserta. Salah satu cara yang bisa ditempuh adalah dengan menjadikannya sebagai prasyarat perkuliahan atau bagian dari mata kuliah, misalnya mata kuliah metodologi penelitian.

4. Memfasilitasi kerja sama

Manakala sumber daya manusia yang ada terbatas dari sisi pengalaman, keterampilan dan keahlian teknis dan dibutuhkan sumber daya tambahan dalam pengembangan gamification, maka pimpinan hendaknya memfasilitasi pelibatan pihak lain dalam proses pengembangan. Pihak lain yang bisa diajak bekerja sama bisa berupa desainer grafis, programmer, dan lain-lain. Di luar negeri, inisiatif seperti ini jamak ditemui.

\section{Kesimpulan dan Saran}

Gamification merupakan metode yang bisa digunakan untuk pengajaran literasi informasi. 
Pengajaran Literasi Informasi ... (Lis Setyowati)

Pengembangan pengajaran literasi informasi ini dianggap relevan untuk menjawab kebutuhan pengajaran literasi informasi kepada generasi digital natives. Dengan karakteristiknya yang mengusung unsur "fun", diharapkan bisa menjadi sarana yang ampuh untuk proses transfer pengetahuan dan penanaman keterampilan kepada generasi digital natives. Dengan demikian, pustakawan harus tahu dan mau harus belajar tentang bagaimana merancang game yang bisa memberikan pengalaman belajar yang menyenangkan, namun benar-benar bisa menjadi sarana untuk belajar secara efektif. Proses ini diharapkan bisa membekali pemustaka yang dibutuhkan dalam menghadapi lansekap informasi yang kompleks dan penuh tantangan sekarang ini.

\section{Daftar Pustaka}

Amr, K. (2012). Learning through Games: Essential Features of an Educational Game. Instructional Design, Development and Evaluation - Dissertations. diakses dari http://surface.syr.edu/cgi/viewcontent. cgi?article=1055\&context=idde_etd. 29 Oktober 2016

Deese, Ashley (2016) 5 Benefits of Gamification, https://ssec.si.edu/stemvisions-blog/5benefits-Gamification diakses tanggal 24 Oktober 2016

Deterding, S., \& Dixon, D. (2011). From Game Design Elements to Gamefulness : Defining " Gamification ," 9-15. diakses dari https://www. cs.auckland.ac.nz/courses/compsci747s2c/ lectures/paul/definition-deterding.pdf. diakses tanggal 24 Oktober 2016

Educause. (2011). EDUCAUSE Learning Initiative 7 Things You Should Know About Gamification. Retrieved from https://library.educause.edu/ / media/files/library/2011/8/eli7075-pdf.pdf. Diakses tanggal 24 Oktober 206
Felker, K. (2014). Gamification in Libraries. Accidental Technologist, 54(2). Diakses dari https:// journals.ala.org/rusq/article/view/2765/2753. Diakses tanggal 24 Oktober 2014

Guo, Yan Ru dan Goh, Dion Hoe-Lian (2016) "Library Escape: User-Centered Design of an Information Literacy Game," The Library Quarterly 86, no. 3 (July 2016): 330-355.. Diakses dari http://www.journals.uchicago.edu/ doi/pdfplus/10.1086/686683. Diakses tanggal 24 Oktober 2016

Kim, B. (2012). Harnessing the power of game, diakses dari $\quad h t t p: / / c r l n . a c r l . o r g / c o n t e n t / 73 / 8 / 465$. Diakses tanggal 24 Oktober 2016

Kim, B. (2015). Understanding Gamification. Diakses dari https://journals.ala.org/ltr/issue/ download/502/252. Diakses tanggal 24 Oktober 2016

Markey, K., Swanson, F., Jenkins, A., Jennings, B., Jean, B. S., Rosenberg, V., ... Frost, R. (2009). Will Undergraduate Students Play Games to Learn How to Conduct Library Research ? The Journal of Academic Librarianship, 35(4), 303-313. doi:10.1016/j.acalib.2009.04.001

Prasetyo, Didik Dwi (2014). Digital Game-Based Learning. Diakses dari http://komunikasi.um.ac. id/2014/12/digital-game-based-learning/. Diakses tanggal 24 Oktober 2016

Prensky, M. (2001a). Fun, Play and Games: What Makes Games Engaging. In Digital Game-Based Learning (pp. 1-31). Diakses dari http://www.marcprensky.com/ writing/Prensky\%20-\%20Digital\%20 Game-Based\%20Learning-Ch5.pdf. Diakses tanggal 24 Oktober 2016

Prensky, M. (2001b). The Games Generations: How Learners Have Changed. In Digital Based Learning (pp. 1-26). McGraw-Hill. Diakses dari http://www.marcprensky.com/ writing/Prensky\%20-\%20Ch2-Digital\%20 Game-Based\%20Learning.pdf. Diakses tanggal 
24 Oktober 2016

Setyowati, Lis (2015) Literasi Informasi dilihat dari Perspektif Modal Manusia. Libraria. Vol. 6 No. 2 Juli-Desember

Smale, M. A. (2011). Learning Through Quests and Contests: Games in Information Literacy Instruction. Journal of Library Innovation, 2(2), 36-55. Diakses dari http:// academicworks.cuny.edu/cgi/viewcontent. cgi?article $=1002 \&$ context $=$ ny_pubs. 24 Oktober 2016

Van Meegen, A. \& Limpens, I., (2010). How Serious Do We Need to Be? Improving Information Literacy Skills through Gaming and Interactive Elements. LIBER Quarterly. 20(2), pp.270-288. DOI: http://doi.org/10.18352/lq.7993

Walsh, A. (2014). The potential for using Gamification in academic libraries in order to increase student engagement and achievement, 6(1), 39-51. Diakses dari https://noril.uib.no/index. php/noril/article/view/214 tanggal 24 Oktober 2016

Walsh, A. (2015). Playful Information Literacy: Play and Information Literacy in Higher Education, 7(1), 80-94. doi:10.15845/noril.v7i1.223. Diakses dari https://noril.uib.no/index.php/ noril/article/view/223. 24 Oktober 2016

Whitton, N (2010). Learning with Digital Games: A Practical Guide to engaging students in higher education. New York, NY; Abingdon, Routledge Young, J. (2016). Can Library Research Be Fun? Using Games for Information Literacy Instruction in Higher Education, 53(3). Diakses dari http://digitalcommons.kennesaw.edu/cgi/ viewcontent.cgi? article $=1973 \&$ context $=$ glq. 24 Oktober 2016 